\title{
GT programs in teacher's education in Ukraine: implementation of foreign experience
}

\author{
M. A. Boichenko \\ Sumy state pedagogical university named after A. S. Makarenko \\ Paper received 22.04.18; Accepted for publication 28.04.18.
}

http://doi.org/10.31174/SEND-PP2018-163VI67-03

\begin{abstract}
The article reveals the author's program of the course "Gifted and talented education: global context" for postgraduate students $(\mathrm{PhD})$ of the pedagogical universities (specialties 01 Education: 011 Educational sciences, 014 Secondary education, 015 Professional education, 016 Special education, 017 Physical culture and sport; 03 Humanities: 035 Philology; 09 Biology: 091 Biology) developed and implemented in Sumy state pedagogical university named after A. S. Makarenko on the basis of studies of the foreign experience (in particular US, UK and Canadian) of providing educational services for GT (gifted and talented) teachers.

Keywords: gifted and talented education, teachers of gifted and talented, GT programs, foreign experience of GT education, postgraduate pedagogical education in Ukraine.
\end{abstract}

Introduction. Importance of special training of GT (gifted and talented) teachers is recognized all over the world. Among the countries where special training is organized at different levels of higher education are the USA, Cana$\mathrm{da}$ and the UK. The universities of these countries offer different bachelor, master and $\mathrm{PhD}$ programs or separate courses for GT teachers. In Ukraine, unfortunately, teachers don't receive special training for work with gifted and talented schoolchildren. Nevertheless, the problem of proper pedagogical support of this category of students is very acute. In this context it seems expedient to implement foreign experience of GT teachers training at higher education institutions.

A brief review of publications on the subject. The professional-pedagogical dimension of research on GT education is represented by studies of Ukrainian scientists on the problems of pedagogical education and professional development of teachers who work or will work with gifted children and youth in Ukraine and abroad (O. Antonova, O. Bocharova, S. Vitvytska, T. Koshmanova, N. Mukan, M. Nahach, H. Nikolai, V. Pohrebniak, N. Polikhun, A. Sbruieva, I. Kholod and others. At the same time, special attention to the problems of GT programs implementation at HEI hasn't been paid yet.

The goal of the article is to introduce the author's program of the course "Gifted and talented education: global context" for postgraduate students $(\mathrm{PhD})$ of the pedagogical universities, developed on the basis of the study of experience of provision of the educational programs for GT teachers at the US, UK and Canadian universities.

Materials and methods. In the article such methods were used: comparative analysis - aimed at defining common features and differences in the implementation of GT teachers training programs at British, American and Canadian universities; scientific extrapolation - for finding the ways of using foreign experience in Ukrainian higher education institutions and developing the program for Ukrainian GT teachers.

Results and discussion. In the USA, Canada and the UK there are different requirements for GT teacher's qualifications and training. For example, in the USA each state and in Canada each province establishes requirements for such qualification. The most general requirement is to obtain a bachelor's degree in a specific specialty, or in primary or secondary education. After that the applicant must obtain a master's degree in education of the gifted and talented. Future teachers in the process of training to work with this category of students learn to identify the gifted and talented through interviewing students and parents and the evaluation of educational achievements. Future teachers of the gifted and talented should get the skills of planning and implementation of appropriate curriculum, the ability to test, evaluate, and distribute students according to their level of academic performance [3]. In the UK the teachers who work with gifted students as a rule get their training in the frames of special education programmes, where gifted are considered one of the category with special educational needs.

In the American universities, for example, there is a number of programs of professional training of future teachers to work with gifted and talented students (primarily at the graduate level), including "Special Education: Gifted Education", "Instruction: Gifted and Talented", "Curriculum \& Instruction Gifted, Creative and Talented", "Gifted Education" and others. Considering the fact that overall programs of master training of the future teachers to work with gifted and talented students are similar, we'd like to analyze the details of one of such programs - "The Master of Education in Instruction: Gifted and Talented", introduced in Wilmington University.

This master's program provides the candidates with theoretical knowledge and practical experience necessary to improve learning for gifted and talented students and ensuring their effectiveness as teachers and school leaders in education of the gifted and talented [4].

The University website (http://www.wilmu.edu/education/medingifted) contains information about this program that provides for the acquisition of knowledge, abilities and skills in the framework of competences outlined in the National Gifted Education Standards, developed in 2008 by the National Association for Gifted Children, Council for Exceptional Children and the Association for the Gifted, namely:

1. Learner Development and Individual Learning Differences - Beginning gifted education professionals understand the variations in learning and development in cognitive and affective areas between and among individuals with gifts and talents and apply this understanding to provide meaningful and challenging learning experiences for individuals with exceptionalities.

2. Learning Environments - Beginning gifted education professionals create safe, inclusive, and culturally 
responsive learning environments so that individuals with gifts and talents become effective learners and develop social and emotional well-being.

3. Curricular Content Knowledge - Beginning gifted education professionals use knowledge of general and specialized curricula to advance learning for individuals with gifts and talents.

4. Assessment - Beginning gifted education professionals use multiple methods of assessment and data sources in making educational decisions about identification of individuals with gifts and talents and student learning.

5. Instructional Planning and Strategies - Beginning gifted education professionals select, adapt, and use a repertoire of evidence-based instructional strategies to advance the learning of individuals with gifts and talents.

6. Professional Learning and Ethical Practice - Beginning gifted education professionals use foundational knowledge of the field and professional ethical principles and programming standards to inform gifted education practice, to engage in lifelong learning, and to advance the profession.

7. Collaboration - Beginning gifted education professionals collaborate with families, other educators, relatedservice providers, individuals with gifts and talents, and personnel from community agencies in culturally responsive ways to address the needs of individuals with gifts and talents across a range of learning experiences [4].

On the basis of study of the experience of the USA, Canada and the UK on the provision of educational services for GT teachers at the higher education institutions, highlighted by the author in a number of studies $[1 ; 2]$, we have developed a course "Gifted and talented education: global context" for postgraduate students $(\mathrm{PhD})$ of the pedagogical universities (specialties 01 Education: 011 Educational sciences, 014 Secondary education, 015 Professional education, 016 Special education, 017 Physical culture and sport; 03 Humanities: 035 Philology; 09 Biology: 091 Biology), which was implemented in Sumy state pedagogical university named after A. S. Makarenko. The course consists of 3 credits ( 90 hours).

The purpose of the course is to form the comparativepedagogical competence of a researcher - highly qualified specialist who has a high level of readiness for professional activity in the field of science and education.

The tasks of the course:

1. Formation of a system of knowledge on the theoretical and methodological foundations of gifted and talented education, its factors and trends of development in the global and regional contexts.

2. Formation of the system of skills in using modern methodology, methods and techniques of comparativepedagogical research in the process of preparation of the dissertation work, its approbation and further professional activity.

3. Development of a system of skills for distinguishing the actual problems of GT education development; interpretations of comparative-pedagogical studies, estimation of their application possibilities and possible risks of their introduction in the domestic educational space, clarification and proper formulation of the prospects for further research in the field of gifted and talented education.
As a result of studying the discipline, the postgraduate student must know:

- theoretical and methodological foundations of GT education as branches of scientific knowledge;

- factors (socio-political, socio-economic, scientifictechnological, cultural-historical) of development of gifted and talented education in conditions of knowledge society;

- trends of innovative development of gifted and talented education in the developed countries and in Ukraine;

be able to:

- conduct critical analysis and evaluation of modern scientific achievements in the field of GT education;

- generate new ideas in solving research tasks, including those in interdisciplinary areas;

- search, process, analyze and contextualize a large amount of scientific information from different sources, interpret the results of comparative and pedagogical research;

- navigate in information and Internet sources on gifted and talented educational issues, work with library funds, and critically treat the information received;

- have ICT culture, realize the values of subjective position in the information space;

- use modern methods and technologies of scientific communication in Ukrainian and English;

- design and implement an individual scientific trajectory, apply the principles of scientific self-organization, own research style;

- work in a scientific group, adhering to ethical norms of professional activity;

- understand modern methodology and methods of scientific-pedagogical research, in particular using the latest information and communication technologies;

- analyze and compare phenomena and processes taking place in the education of gifted and talented students in different countries;

- analyze, compare the theoretical views of researchers on the processes and phenomena taking place in GT education in different countries and in the world as a whole;

- analyze the consequences of development of the educational processes, the difference between educational phenomena that are universal, special and individual;

- assess the impact of socio-political, socio-economic, scientific, technical, and cultural-historical factors on the development of gifted and talented education of different countries and the world as a whole;

- express their own point of view in oral and written form in Ukrainian and English on trends in the development of gifted and talented education that are observed in different regions of the world and Ukraine.

The program of the discipline "Gifted and talented education: global context" includes three sections.

Section I. Theoretical and methodological foundations of GT education.

Unit 1. Education of gifted and talented as a branch of scientific knowledge: modern conceptual approaches.

Unit 2. Theoretical and methodological approaches to the study of the nature of giftedness.

Unit 3. The essence and structure of giftedness.

Section II. Pedagogical support of gifted and talented children and youth at different stages of training. 
Unit 4. Methods of identification of gifted and talented at different stages of training.

Unit 5. Creation of an environment of gifted and talented support within the general and extracurricular education institutions.

Unit 6. Differentiation of learning of talented and talented students.

Unit 7. Psychological-pedagogical support of gifted and talented children and youth.
Section III. Modern trends of innovative development of GT education.

Unit 8. Ensuring quality of GT education on the principles of equality and justice.

Unit 9. Trends of GT education technologization.

Unit 10. Trends of higher GT education development.

Unit 11. Educational policy of international organizations in the field of GT education.

The structure of the course is presented in table 1.

Table 1. The structure of the course "Gifted and talented education: global context"

\begin{tabular}{|c|c|c|c|c|c|c|c|c|c|c|c|c|}
\hline \multirow[b]{4}{*}{ Sections and units } & \multicolumn{12}{|c|}{ Number of hours } \\
\hline & \multicolumn{6}{|c|}{ Full time } & \multicolumn{6}{|c|}{ Part time } \\
\hline & \multirow[b]{2}{*}{ हैं } & \multicolumn{5}{|c|}{ including } & \multirow[b]{2}{*}{ 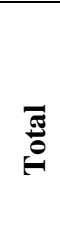 } & \multicolumn{5}{|c|}{ including } \\
\hline & & 异 & 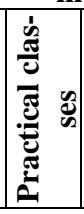 & 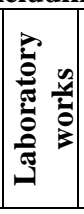 & 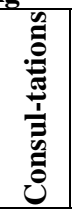 & 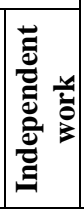 & & 苞 & 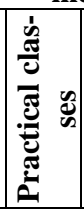 & 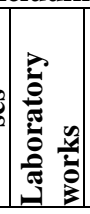 & 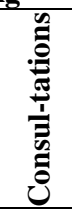 & 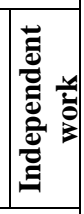 \\
\hline \multicolumn{13}{|c|}{ Section I. Theoretical and methodological foundations of GT education } \\
\hline $\begin{array}{l}\text { Unit 1. Education of gifted and talented as a branch of } \\
\text { scientific knowledge: modern conceptual approaches }\end{array}$ & 8 & 2 & - & - & - & 6 & & & & & & \\
\hline $\begin{array}{l}\text { Unit 2. Theoretical and methodological approaches to } \\
\text { the study of the nature of giftedness }\end{array}$ & 7 & 1 & 2 & - & - & 4 & & & & & & \\
\hline Unit 3. The essence and structure of giftedness & 7 & 1 & 2 & - & - & 4 & & & & & & \\
\hline \multicolumn{13}{|c|}{ Section II. Pedagogical support of gifted and talented children and youth at different stages of training } \\
\hline $\begin{array}{l}\text { Unit 4. Methods of identification of gifted and talented } \\
\text { at different stages of training }\end{array}$ & 7 & 1 & 2 & - & - & 4 & & & & & & \\
\hline $\begin{array}{l}\text { Unit 5. Creation of an environment of gifted and talent- } \\
\text { ed support within the general and extracurricular educa- } \\
\text { tion institutions }\end{array}$ & 7 & 1 & 2 & - & - & 4 & & & & & & \\
\hline $\begin{array}{l}\text { Unit 6. Differentiation of learning of talented and tal- } \\
\text { ented students }\end{array}$ & 7 & 1 & 2 & - & - & 4 & & & & & & \\
\hline $\begin{array}{l}\text { Unit 7. Psychological-pedagogical support of gifted and } \\
\text { talented children and youth }\end{array}$ & 6 & & 2 & - & - & 4 & & & & & & \\
\hline \multicolumn{13}{|c|}{ Section III. Modern trends of innovative development of GT education } \\
\hline $\begin{array}{l}\text { Unit 8. Ensuring quality of GT education on the princi- } \\
\text { ples of equality and justice }\end{array}$ & 6 & - & 2 & - & - & 4 & & & & & & \\
\hline Unit 9. Trends of GT education technologization & 6 & - & 2 & & & 4 & & & & & & \\
\hline Unit 10. Trends of higher GT education development & 6 & - & 2 & & & 4 & & & & & & \\
\hline $\begin{array}{l}\text { Unit 11. Educational policy of international organiza- } \\
\text { tions in the field of GT education }\end{array}$ & 7 & 1 & 2 & & & 4 & & & & & & \\
\hline Independent work & 16 & & 2 & & & 14 & & & & & & \\
\hline Total hours & 90 & 8 & 22 & & & 60 & & & & & & \\
\hline
\end{tabular}

The course "Gifted and talented education: global context" is optional. It is taught at 4 semester (2 year of training). It gives young Ukrainian researchers the opportunity to get acquainted with such sphere as GT education, deepen knowledge on the nature of giftedness and theoretical-methodological and practical foundations of GT education.

Conclusions. We hope that proposed program will be implemented in other Ukrainian universities and it will become the beginning of the GT teachers' education in our country, because in order not to leave behind our future national elite - gifted and talented students - it is necessary to have enough knowledge on the nature and modern concepts of giftedness, methods and technologies of GT students' identification, special educational services provision, which can be gained in the process of special training.

\section{ЛІТЕРАТУРА}

1. Бойченко, М. А. Програми професійної підготовки майбутніх учителів до роботи з обдарованими і талановитими школярами в університетах США, Канади та Великобританії // Педагогічні науки: теорія, історія, інноваційні технології, 2015, 1 (45), С. 10-17.

2. Бойченко, М. А. Підготовка майбутніх учителів до роботи 3 обдарованими учнями у вищих навчальних закладах США, Канади та Великої Британії // Вісник Черкаського університету. Серія Педагогічні науки. Черкаський наці- ональний університет імені Богдана Хмельницького. Черкаси, 2016, 2, С. 18-23.

3. Gifted and Talented Teacher Career. Teacher Certification Degrees. Retrieved from: http://tcd.wpengine.netdnacdn.com/careers/gifted-talented-teacher/

4. Instruction: Gifted and Talented: Master of education. Wilmington University. Retrieved from:

http://www.wilmu.edu/education/medingifted_admission.aspx 


\section{REFERENCES}

1. Boychenko, M. A. Programs of the future teachers' professional training to work with gifted and talented students at universities in the USA, Canada and UK // Pedagogical sciences: theory, history, innovative technologies, 2015, 1 (45), P. 10-17.

2. Boichenko, M. A. Training future teachers to work with gifted students in higher education institutions of the USA, Canada and the UK // Bulletin of Cherkasy University. Series Pedagogical Sciences. Cherkasy National University named after Bogdan Khmelnytsky. Cherkasy, 2016, 2, P. 18-23.

\section{ОТ программы в образовании учителей в Украине: внедрение зарубежного опыта}

\section{М. А. Бойченко}

Аннотация. В статье раскрывается авторская программа курса «Образование одарённых и талантливых: глобальный контекст» для аспирантов педагогических вузов (специальностей 01 Образование: 011 Науки об образовании, 014 Среднее образование, 015 Профессиональное образование, 016 Специальное образование, 017 Физическая культура и спорт; 03 Гуманитарные науки: 035 Филология; 09 Биология: 091 Биология), разработанная и внедренная в Сумском государственном педагогическом университете имени А. С. Макаренко на основе изучения зарубежного опыта (в частности, США, Великобритании и Канады) предоставления образовательных услуг учителям ОТ (одарённых и талантливых).

Ключевые слова: образование одарённых и талантливых, учителя одарённых и талантливых, ОТ программы, зарубежный опыт ОТ образования, последипломное педагогическое образование в Украине. 